FE DE ERRATA

\title{
La Familia Calyptraeidae en el Perú (Gastropoda: Caenogastropoda) -Fe de errata
}

\section{The family Calyptraeidae in Peru (Gastropoda: Caenogastropoda) -Fe de errata}

\section{Carlos Paredes y Franz Cardoso}

Universidad Nacional Mayor de San Marcos, Facultad de Ciencias Biológicas, Laboratorio de Biología y Sistemática de Invertebrados Marinos, Apdo. 11-0058, Lima 11, Perú. y Departamento de Malacología, Museo de Historia Natural, Universidad Nacional Mayor de San Marcos, Apdo. 14-0434, Lima 14, Perú. E-mail: Carlos Paredes cparedesq@unmsm.edu.pe

Rev. peru. biol. número especial 13(3): 177 - 184 (Julio 2007)

Error en la figura 1 y 2 : las imágenes de las fotos se encuentran volteadas en $180^{\circ}$, es decir las fotos son imágenes especulares.

Error in Figure 1 and 2: the images of the photos are turned $180^{\circ}$, ie. each photo is the mirror image. 


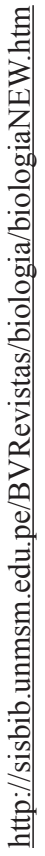

